\title{
On Lorentz Spengler and a neotype for the foraminifer Calcarina spengleri
}

\author{
HANS JØRGEN HANSEN
}

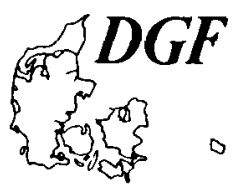

Hansen, H. J.: On Lorentz Spengler and a neotype for the foraminifer Calcarina spengleri. Bull. geol. Soc. Denmark, vol. 29, p. 191-201. Copenhagen, January 26th, 1981.

https://doi.org/10.37570/bgsd-1980-29-14

In 1781, Lorentz Spengler, curator of the Royal Collection of Art, Crafts and Rarities of Nature, Denmark (1771-1807), described several foraminifera from sand obtained from the interior of large gastropods. On sectioning these minute foraminiferal tests he observed that they had no siphuncle (thus predating d'Orbigny's well-known observation of 1826) and that the septa curved in the opposite direction to those of Nautilus "and the Ammon's Horn". One of Spengler's species was named Calcarina stellata by de Férussac in 1827. This is a valid senior subjetive synonym of Pararotalia calcar (d'Orbigny, 1839), and an application has therefore been made to the International Commission on Zoological Nomanclature for its suppression.

The type species of the genus Calcarina was described and illustrated by Spengler (1781) and named Nautilus spengleri by Gmelin (1791). The type was described from sand contained in an east Indian gastropod. The gastropod has been located in the Zoological Museum, Copenhagen. It still contained some sediment, from which a neotype has been selected.

Hans Jørgen Hansen, Geological Central Institute, University of Copenhagen, Øster Voldgade 10, DK-1350 Denmark, June 6th, 1980.

Lorentz Spengler was born in Schaffhausen, Schweitz, in 1720 (Brock, 1902). He was trained in artistic turning in Regensburg, Germany from 1734 to 1739 and after that worked for 4 years as a turner in Bern. Being a gifted craftsman he went to London in 1743 and tried to make a living, but the conditions were not favourable, and so, along with two friends, he went to Copenhagen. In Copenhagen Spengler was appointed royal turner in 1745 . He got a workshop in the palace and taught the Royal Family the art of turning. Many of the results of Spengler's efforts and those of his royal pupils can be seen in the Rosenborg Palace in Copenhagen.

In addition to his duties at the court Spengler had a private workshop in town where he taught turning and produced false teeth carved of ivory or narwhal tusk. He was a polyhistor with very broad interests, and even had a private electrotherapeutical clinic in Copenhagen where he treated people for lameness with his home-made machinery (Snorrason 1974). He collected paintings and copper engravings, but his main interest was, however, his large collection of shells, which was internationally famous. The Empress of Russia, Catharina II wanted to buy the collection, but Spengler refused to sell.
Spengler published a series of papers on gastropods, bivalves and a variety of other subjects. He was co-author of the text accompanying the molluscan work by Regenfuss in 1758 (Nyerup and Kraft, 1820).

Spengler corresponded extensively with other collectors. Two letters from Linné were published by Steenstrup (1849). Some of Spengler's letters are kept in the archives of the Zoological Museum, while other written materials are in the archives of the Royal Museum of Fine Art. In the latter archives are also the catalogues of his belongings which were sold at a public auction after his death in 1807. The papers are now preserved in the Royal Museum of Fine Art through Conrad Spengler, son of Lorentz, who was the first Director of that Museum.

Spengler became a member of the Royal Danish Academy of Sciences and Letters in 1778. His portrait was engraved four times, (1762, $1776, ? 1785,1802)$ : that shown on fig. 1 dates from 1776.

In 1781 Lorentz. Spengler published two almost overlooked papers on foraminifera in the series of the Royal Danish Academy of Sciences and Letters. Although originally written in German (Spengler's mother tongue) they were 


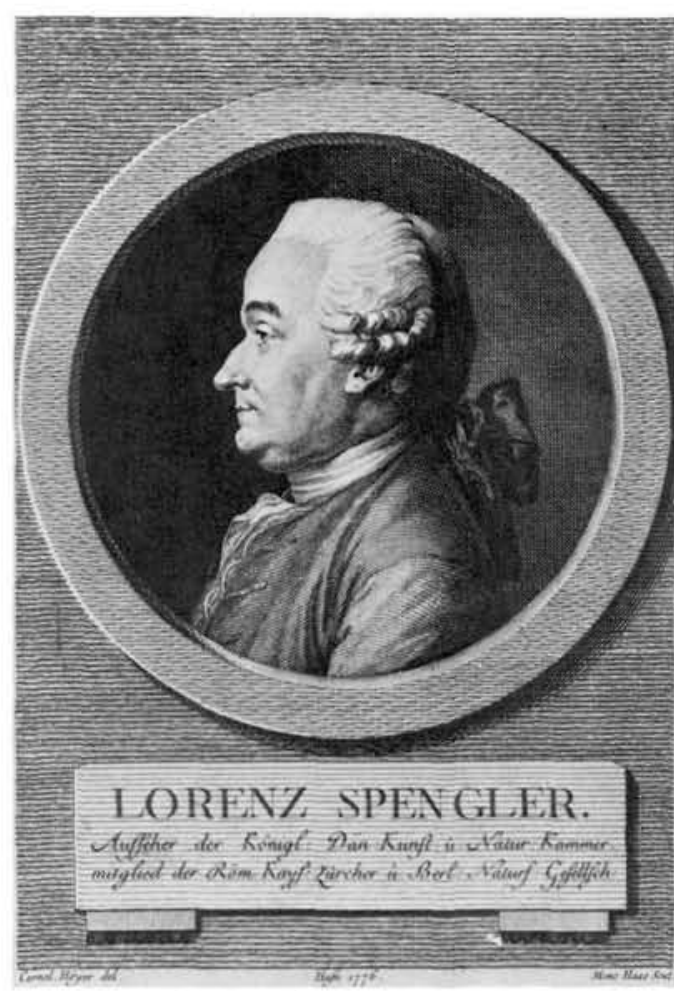

Fig. 1. Lorentz Spengler. Copperengraving from 1776.

translated into Danish, a language which Spengler apparently did not master completely at that time. The fact that they were published in Danish may well account for their lack of impact on research in foraminifera. The forms described were illustrated on two plates with excellent copper engravings.

Spengler did not use Linné's system of nomenclature for the foraminifera though he used Linnéan names for bivalves and gastropods which he described in other papers. His descriptions and illustrations of two species of foraminifera were used by Gmelin (1791) for Nautilus spengleri and by de Férussac (1827) for Calcarina stellata.

It is generally accepted that d'Orbigny in 1826 was the first to recognize the difference between cephalopods with a siphuncular tube and other "cephalopods" without this tube. The latter group was called "foraminifères" by d'Orbigny, since the shells have holes between the chambers (the former apertures). In 1826 d'Orbigny regarded the foraminifera as belonging to the cephalopods.
However, already in 1781 Spengler noticed that when he sectioned the "small snails" from molluscan sand he was unable to observe any "nerve rør" (nerve tube), and he very much doubted that they had any at all. He compared the small forms with both Nautilus, Spirula and Lituites and noticed that the small forms differed not only in lacking a siphuncular tube, but also in the curvature of the septa which in the small forms was opposite that of Nautilus.

At some length Spengler describes how he obtained the material. In his large collection of shells were some large gastropods, and he considered the possibility of getting material out from the columella of these (especially from the east Indian large "Storm Caps" = Cassis). With some satisfaction he ascertains that sand with a content of small chambered shells occurs at many other localities than Rimini which was not known in 1781. He mentions that he has found small shells (foraminifera) in the agglutinated tube of a Sabella, between the roots of Sea Grass and especially in bivalves and gastropods (i.a. from the Red Sea).

In gastropods from the Coromandel Coast, south of Madras, India, Spengler found a form which de Férussac in 1827 named Calcarina stellata. The indication by Spengler as to which gastropod yielded the material is not distinct. $\mathrm{He}$ writes that the form is present in "Kokillier" (shells) from the area. The figures (reproduced on $\mathrm{Pl} .1$ ) leave little doubt that the species is $\mathrm{Cal}$ carina calcar d'Orbigny, 1826. However, Calcarina calcar d'Orbigny (= Pararotalia calcar) as listed by d'Orbigny in 1826 is a nomen nudum since it was not illustrated or described, but only depicted by a plaster model. In his list from 1826 d'Orbigny mentioned as localities Martinique, Mauritius and Madagascar. In the 12 samples from Mauritius housed in our laboratory we have found only one form which can be conspecific with the model of d'Orbigny. This form (Pl. 2 fig. $1-2)$ is in good accordance with the generally accepted and used concept of the species Pararotalia calcar. Thus, there is little doubt as to what d'Orbigny meant. More recent work on the foraminifera from the east coast of India indicates that Pararotalia calcar occurs in shallow water (Vedantam and Rao, 1970).

In his work on foraminifera from Cuba d'Orbigny (1839) described and illustrated the species 
Calcarina calcar, and recently Le Calvez (1977) selected a lectotype from the material of d'Orbigny from the West Indies. As a consequence Calcarina calcar must date from 1839 and not from 1826. According to Dr. Yolande Le Calvez (pers. comm.) no specimens of C. calcar from 1826 are preserved.

If the principle of priority as outlined in the Rules of Zoological Nomenclature was to be followed in the present case it would lead to absolute confusion, since $P$. calcar has a very wide distribution in the Recent seas and consequently has been mentioned numerous times. Further the name is in common use. Therefore, the author has applied to the International Commission on Zoological Nomenclature to ask for suppression of the valid senior synonym of $P$. calcar, namely Calcarina stellata de Férussac, 1827 (application Z. N. (S) 2344).

Spengler also described two species from the Red Sea (sand from the coast of Arabia Felix = Saudi Arabia) and the Gulf of Suez. The material was collected by Forskål during an expedition in the period 1761-1767 to the above mentioned areas (Wolff, 1968) and kept in the "Kunstkammer" (The Royal collection of Arts, Crafts and Rarities), for which Spengler had become curator in 1771. These two foraminiferal species can be identified from the figures, as Spirolina arietina (Batsch, 1791) and Peneroplis planatus (Fichtel \& Moll, 1798) (compare Pl. 1, figs. 10a-f and Pl. 2, figs. 3-5).

In his second contribution in the Royal Danish Academy Spengler described a form from the sand contained in a large Cassis, mentioned as the Amboinic "Storm Cap" (by Gmelin 1791 mentioned as Buccinum cassideum from East India). Amboinia or Ambon is close to the island Ceram in the Moluccan archipelago. Spengler's description and figures were used by Gmelin, 1791 in the XIIIth edition of Systema naturae. Gmelin named the species Nautilus spengleri and the species thereby became valid. The specimen depicted by Spengler (reproduced on Pl. 3) represents the holotype.

Spengler's private collection of shells was purchased by the Danish King in 1804 for a large sum of money and added to the Royal collection. In the early 1820 es the Royal collection was divided and the shell collection was later transferred to the University (Zoological Museum),
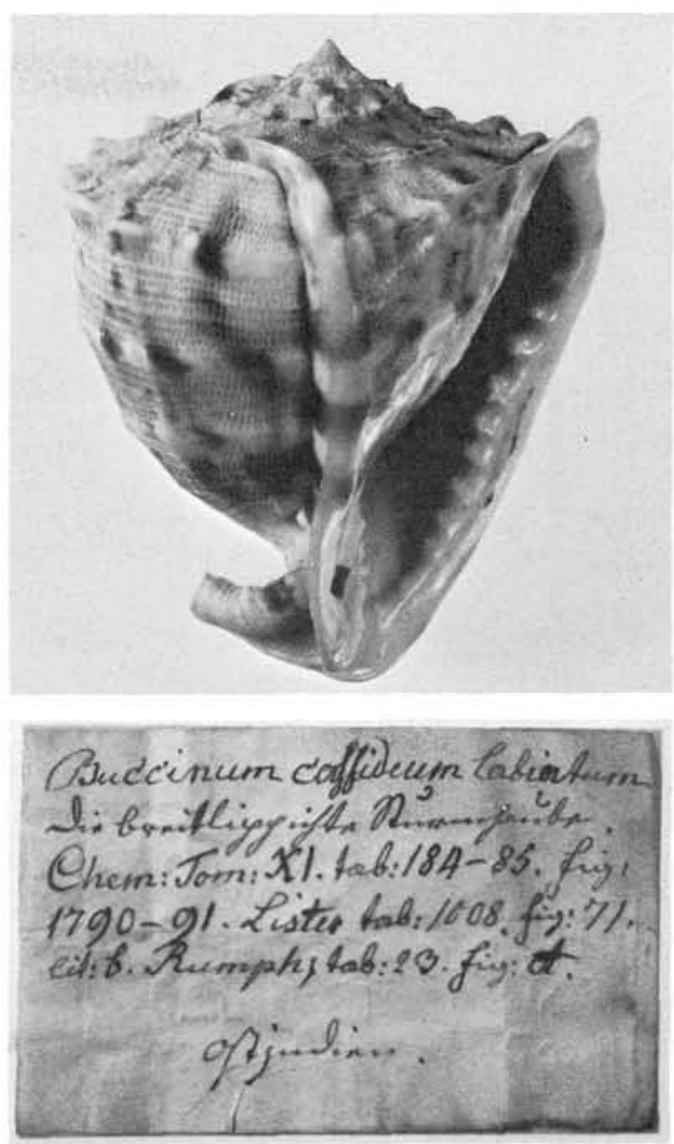

Fig. 2. The source of Calcarina spengleri (Gmelin, 1791). Height of the shell $12.5 \mathrm{~cm}$. Specimen from Spengler's collection in the Zoological Museum, Copenhagen. Below the gastropod is shown the original label. In addition to the name Buccinum cassideum several references are listed. They concern Chemnitz, Lister and Rumph. The locality is "Ostindien".

where it is still kept. The author visited the collection and found the original gastropod with the label written by Spengler (fig. 2). Material from this gastropod is thus from the type locality of Calcarina spengleri (presumably Ambon, Moluccas).

There are no foraminifera preserved in the Spengler collection at the Zoological Museum. However, some of Spengler's material was fossil, and for many years it was used as a demonstration collection in the Zoological Museum. In 1935 it was transferred to the Geological Museum, but a search in this material has not revealed any specimens of Calcarina spengleri. The only samples are of nummulitic limestones from Egypt. 

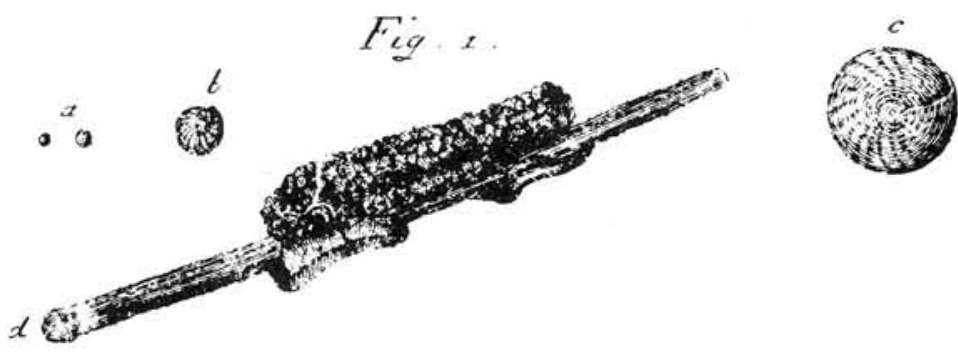

$$
F_{2}^{-1} 2
$$

$t$

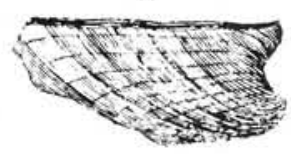

$a$

$c$
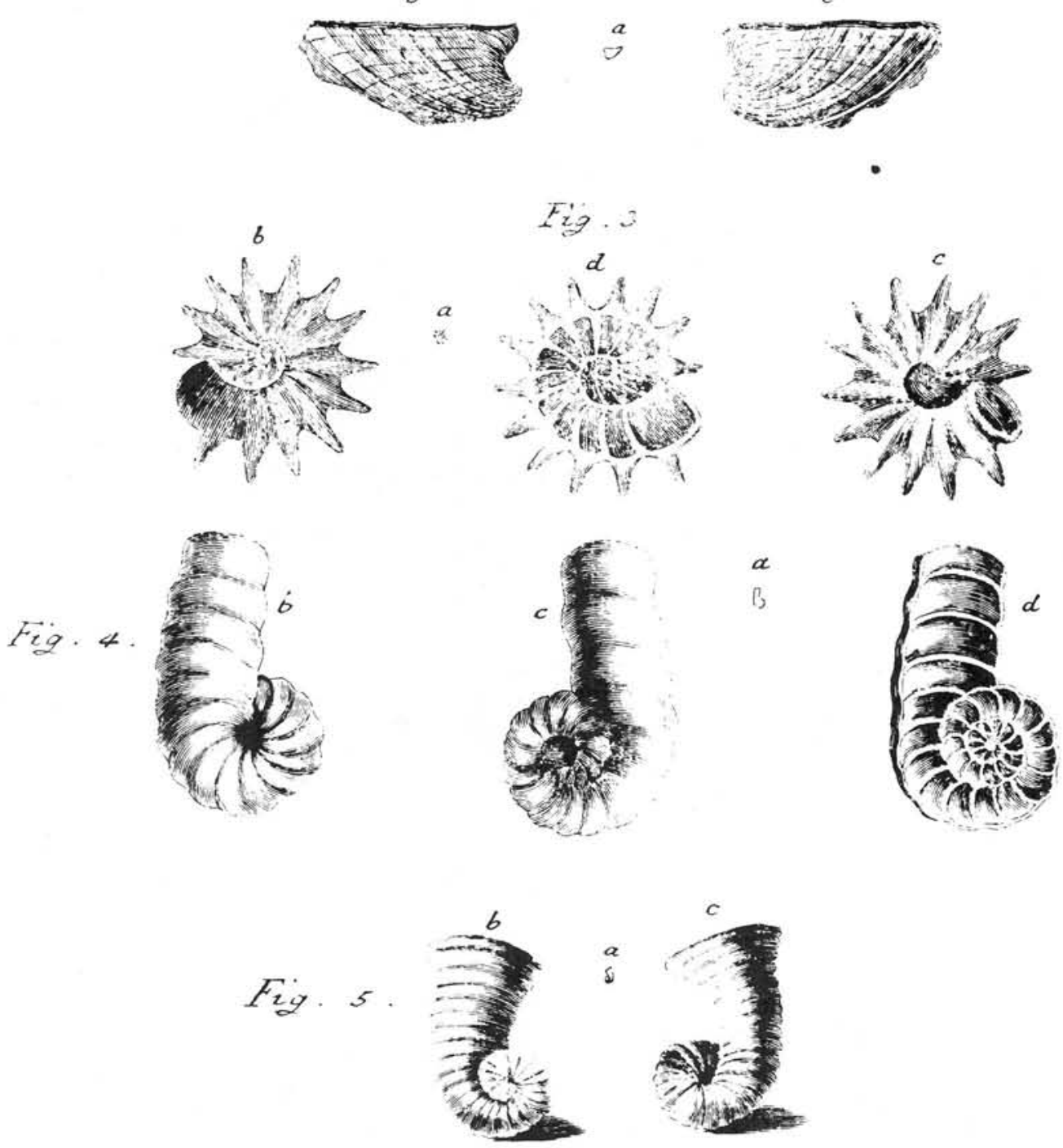

PLANCE 1

Peter Haces fud

Reproduction of Table I from Spengler (1781a). Fig. Ia-c. ?Elphidium crispum from the tube of Sabella attached to a spine from a sea urchin from Marseilles, France. The spine and Sabella tube shown in fig. 1d. Fig. 2a-c. Chambered shell of unknown affinity. De Férussac (1827) referred the form to Planularia. Fig. 3a-d. Calcarina stellata de Férussac, 1827 (= Pararotalia calcar (d'Orbigny, 1839)). a - actual size; b - spiral side; c- umbilical side; d - sectioned specimen. Fig. 4 a-d. Spirolina arietina (Batsch, 1791). Red Sea, a - actual size; b \& c - side views; d-sectioned specimen. Fig. 5 a-c. Peneroplis planatus (Fichtel \& Moll, 1798). Red Sea. a actual size; b \& c - side views. 


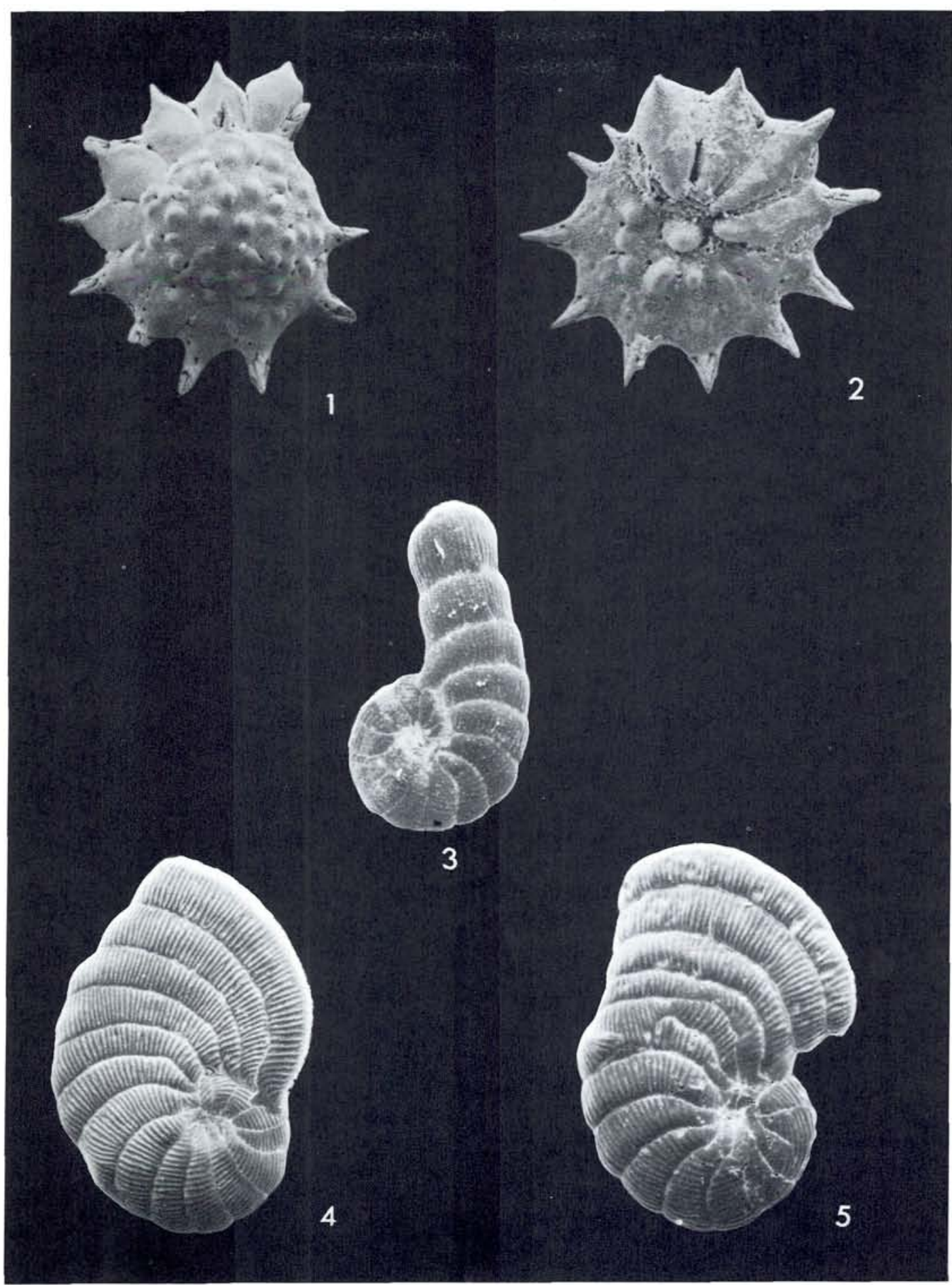

PLATE 2

Fig, 1-2. Calcarina stellata de Férussac, 1827 (= Pararotalia calcar d'Orbigny, 1839). Recent, Mauritius. $1-$ Spiral side $90 \times .2-$ Umbilical side $90 \times$. Fig. 3. Spirolina arietina (Batsch, 1791). Recent, Ras Muhammad, Sinai, Red Sea. $67 \times$. Fig. 4-5. Peneroplis planatus (Fichtel \& Moll, 1798). Recent, Ras Muhammad, Sinai, Red Sea. 4 - side view of ordinary form $50 \times$. 5 - Side view of somewhat irregular specimen. $68 \times$. 
S. 378 .

Fig. 7 .

Tab. II.

a 3
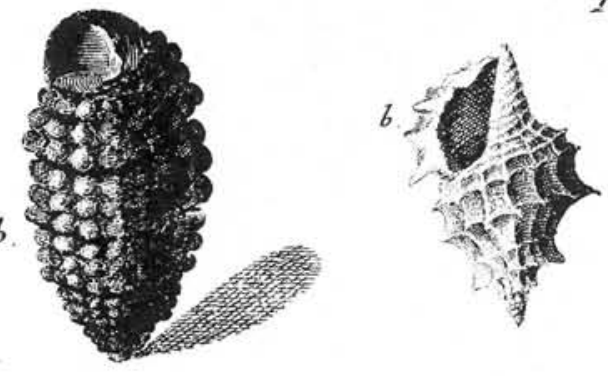

Fig. $\&$

Fiy.o
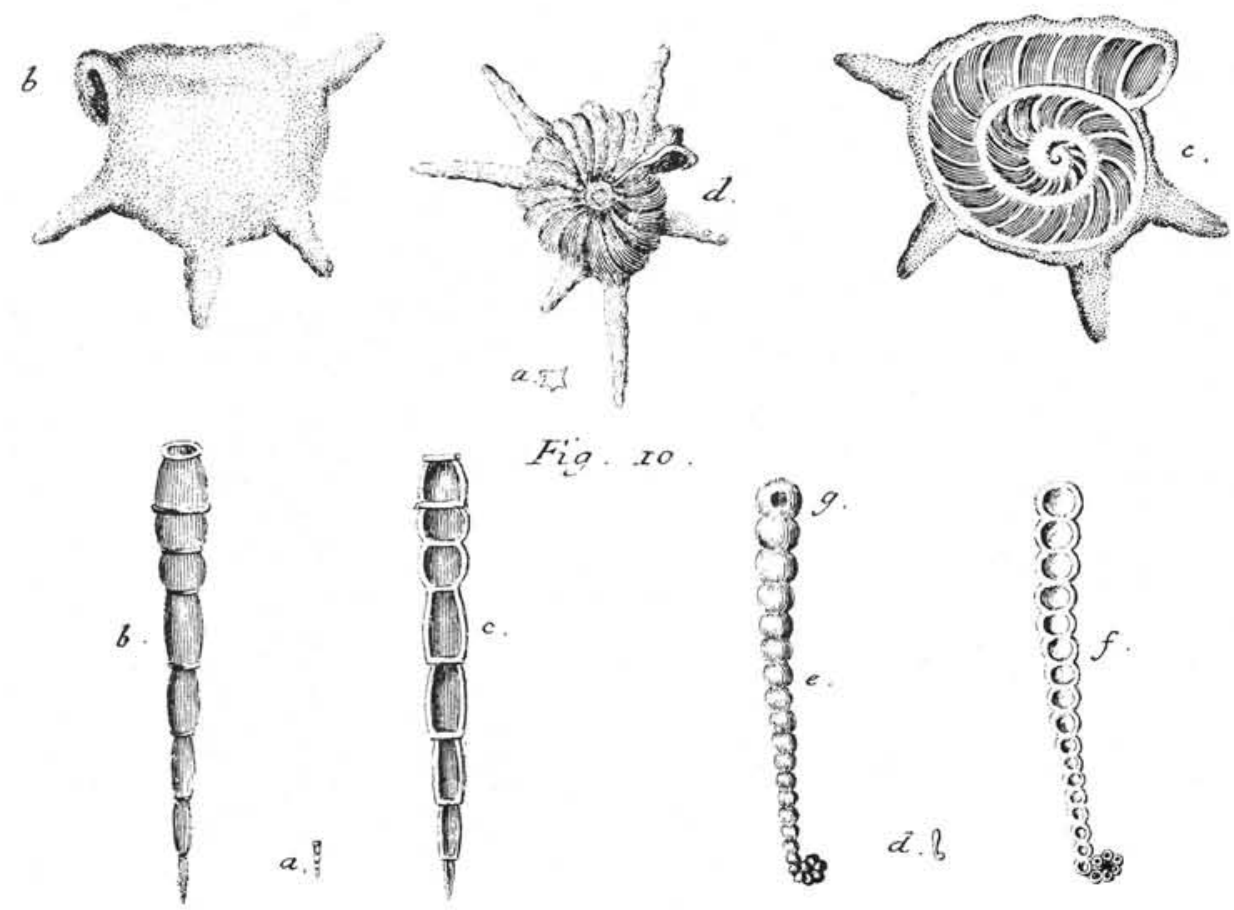

Fig no.
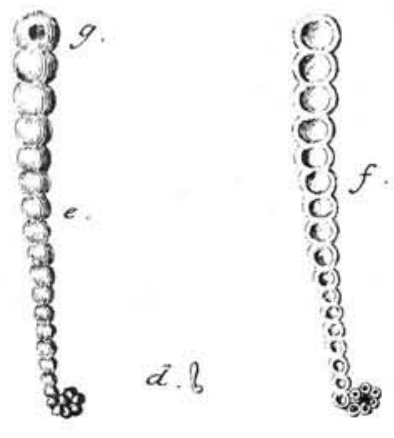

Peter Hans fartp

PLANCE 3

Reproduced from Spengler (1781b). Fig. 7-8. Gastropods. Fig. 9a-c. Calcarina spengleri (Gmelin, 1791). East India. a - actual size; $\mathrm{b}$ - presumably spiral side of specimen with fractured final chamber; c - sectioned specimen. Fig. 9d. Asterorotalia unguiculatus (Gmelin, 1791). East India. Fig. 10 a-c. Articulina pacifica Cushman, 1944. Red Sea. a - actual size; b - side view; c - sectioned specimen. Fig. $10 \mathrm{~d}-\mathrm{f}$. Spirolina acicularis (Batsch, 1791). Red Sea. $\mathrm{d}$ - actual size; e - side view; $\mathrm{f}$ - sectioned specimen. The letter "g" refers to a hole in the final chamber which Spengler noted in several specimens. 


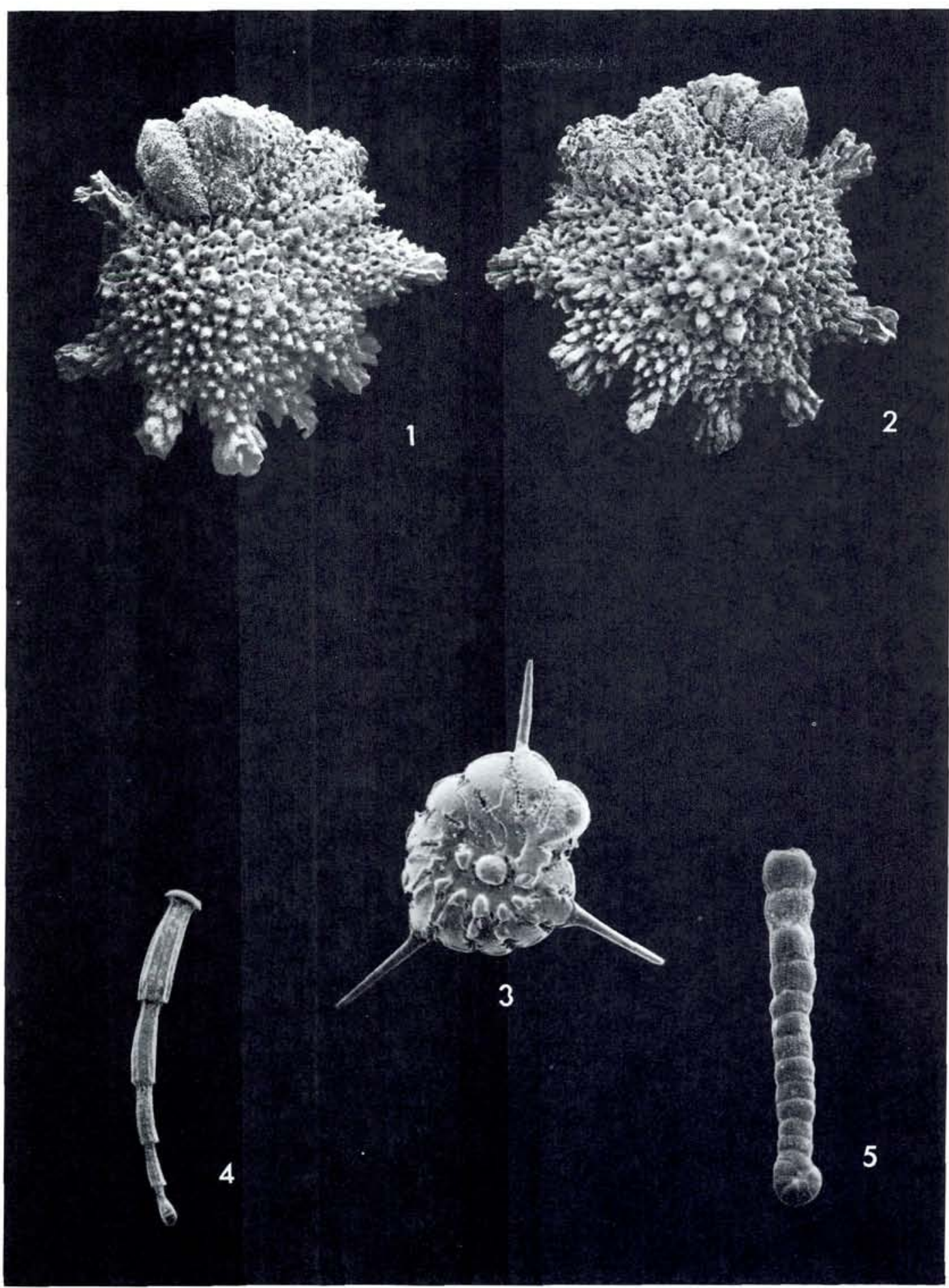

PLATE 4

Fig. 1-2 Calcarina spengleri (Gmelin, 1791). From sand contained in Buccinum cassideum from East India. 1 - umbilical side of neotype; 2 - spiral side of neotype. Both $55 \times$. Fig. 3. Asterorotalia pulchella (d'Orbigny, 1839). Recent, Banda Island. Umbilical side. $68 \times$. Spengler mentioned the variable number of spines in his description. Fig. 4. Articulina pacifica Cushman, 1944. Recent, Ras Muhammad, Sinai, Red Sea. 43 x. Fig. 5. Spirolina acicularis (Batsch, 1791). Recent, Ras Muhammad, Sinai, Red Sea. $128 \times$. 
The Buccinum cassideum specimen was $\mathrm{X}$-rayed in order to see if any sandy material could still be contained in the columella region. The radiographs showed a concentration of sand in the early part of the shell, and the Zoological Museum kindly granted permission to drill a small hole to recover the sediment. About $2 \mathrm{~cm}^{3}$ of coarse carbonate sand were obtained. It contained 52 specimens of Calcarina spengleri.

These specimens fit Spengler's description. There is a wide range of variation in the development of the peripheral spines and in the degree of the development of the surface sculpture.

Spengler generously provided material of sand from his shells to other scientists. Thus Fichtel \& Moll (1798) thank him for material of 8 of the 35 species described by them. Among these is a series of specimens of $C$. spengleri still preserved and depicted by Fichtel \& Moll and now illustrated by scanning electron microscopy by Rögl \& Hansen (in prep.) in their revision of the Fichtel \& Moll collection.

Spengler's description (1781, p. 379-380) of Calcarina spegleri (Gmelin, 1791) reads (translated from Danish): "Fig. IX a, b, c, also shows a form from the shell and coral dust from the large Amboinic Storm Cap. As this multichambered shell is neither enrolled like Nautilus or has coils that can be seen on the surface like in Ammon's Horns (the characters which the taxonomists have used to separate the two genera) I am not sure to which genus it should be referred. However, it can provisionally be placed in the second genus. This shell occurred in large quantities in the above mentioned coral and shell gravel. They are very variable, which, however, may be attributed to differences in age or to stages of growth. Some of them have, on the edge of the dorsal side, from 3 to 7 variably spaced projecting spines of different size. Others have numerous short spines like a comb, while others that are still small and young generally have three long spines.

The whole surface, including the spines, is uneven-like shagreen - and is constructed of small warts, which through the hand lens seem shiny and smooth. On some specimens, particularly on their broad surface, there are wart-like elevations and stalactitic deposits. One of the surfaces is vaulted, the other, carrying the aperture, is somewhat flatter, but on neither side is seen any trace of coils. The shape is everywhere without edges or corners, but is smoothly rounded as though formed in dough. The space where the animal lived is equally smoothly infolded. The aperture is equipped with a backward folded seam. The opening is finely marked at $b$ and bends in an inward direction towards the flat side of the shell.

The general outline is always circular, but in a somewhat disorderly way. When they are sectioned (which is easy, since the shell is strong and not brittle, and large enough) one may observe a large number of septa and chambers (as in Nautilus and the Ammon's Horns).

There are from 40 to 50 chambers. The shells are straw coloured. Their natural size can be seen at $\mathbf{a} ; \mathbf{b}$ is enlarged and shows the lower flat side with the aperture, and $\mathrm{c}$ is a sectioned shell with its chambers."

One of the specimens of $C$. spengleri from the gastropod is here selected as neotype for Nautilus spengleri Gmelin, 1791 (pl. 3, figs. 1-2). The neotype is deposited in the Geological Museum, University of Copenhagen (Reg. nr. MGUH 15076).

The variation of the species is demonstrated on pls. 5-6.

The inner structures were described by Hansen $\&$ Reiss (1971) who found $C$. spengleri to be a bilamellar form with septal flaps, and, only in the initial part an umbilical cover plate. This character clearly distinguishes it from Pararotalia which has an umbilical cover plate in the adult.

The remaining specimens depicted by Spengler (1781, table II) originate from the Red Sea. They were contained in the sediment inside an Arca noae and can probably be identified as Articulina pacifica Cushman, 1944 and Spirolina acicularis (Batsch, 1791).

Two Recent specimens from the Red Sea are depicted on pl. 4 for comparison.

Acknowledgements. The author is indebted to the staff of the Zoological Museum, the Royal Museum of Fine Art and the Geological Museum for help with the museum files. R. G. Bromley kindly $x$-rayed the gastropod. 


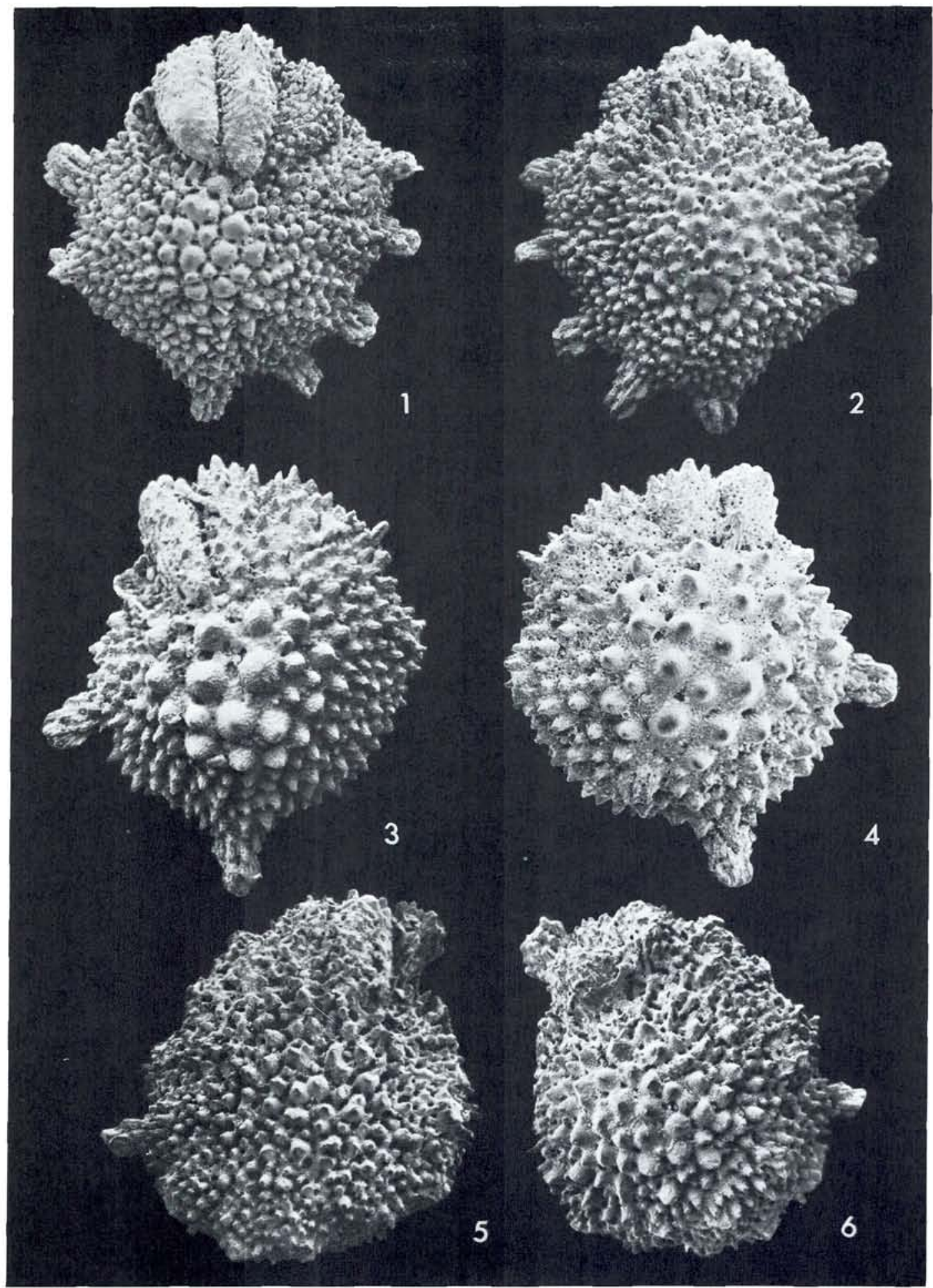

PLANCE 5

Fig. 1-6. Calcarina spengleri (Gmelin, 1791). From sand contained in Buccinum cassideum from East India. Topotypes. 1 \& $2-65 \times$; $3 \& 4-93$ x: $5 \& 6-54 \times$. 


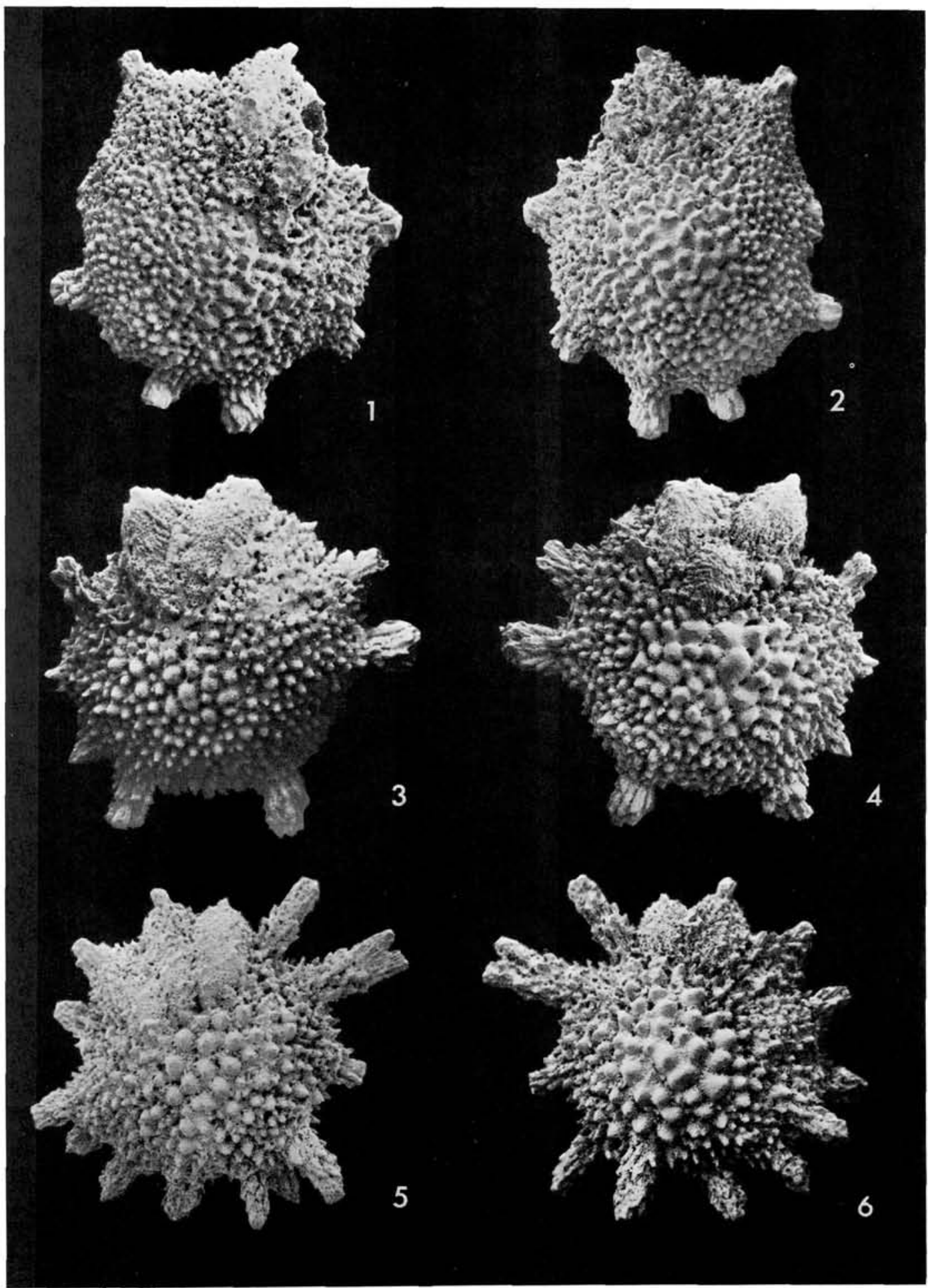

PLANCE 6

Fig. 1-6. Calcarina spengleri (Gmelin, 1791). From sand contained in Buccinum cassideum from East India. Topotypes. $1 \& 2-50 \times$; $3 \& 4-64 x ; 5 \& 6-51 \times$. 


\section{Dansk sammendrag}

Kongelig kunstdrejer og kunstkammerforvalter Lorentz Spengler (1720-1807) beskrev i 1781 på dansk forskellige foraminiferer, som han fandt $i$ det sand, han rystede ud af store snegleskaller. Ved at slibe foraminiferskallerne kunne han konstatere, at de ikke besad en sipho ("nerverør") og at kammerskillevæggene buede den modsatte vej af skillevæggene hos Nautiler. Disse iagttagelser tilskrives normalt den franske forsker d'Orbigny (1826). Årsagen til at disse iagttagelser ikke blev kendt $i$ videre kredse må søges $i$ at Spenglers arbejder er trykt på dansk. Spengler navngav ikke de foraminiferer han beskrev og afbildede.

De Férussac (1827) navngav en af Spenglers arter, Calcarina stellata. Den er et ældre synonym for Calcarina calcar d'Orbigny, 1839. Det er en uhyre almindelig lavtvandsform $i$ troperne og subtroperne. Af hensyn til stabilitet i navngivningen er den Internationale Zoologiske Kommission blevet bedt om at undertrykke Spenglers (dvs. de Férussacs) art, idet den ikke har været brugt.

Typearten for slægten Calcarina er en art beskrevet og afbildet af Spengler. Den blev 10 år senere navngivet af Gmelin som Nautilus spengleri. Typelokaliteten, en bestemt ostindisk snegl fra Spenglers samling, er fundet på Zoologisk Museum. I sneglen var"der bevaret sand i hvilket 52 eksemplarer af arten blev fundet. Et af disse er udvalgt som neotype. Ironisk nok er lokaliteten for "typelokaliteten" ukendt.
References

Brock P. M J 1902: Lorentz Spengler in Dansk biografisk Lexicon, 16, 209-211. (In Danish)

Férussac, A. de 1827: Additions et corrections au Tableau méthodique de la classe des Céphalopodes, par M. d'Orbigny; Ordre des foraminiferes. Bull. Sci. Nat. Geol. Paris, $10,175-185$

Gmelin, J. F. 1791: Systema naturae Linnaei. 13th ed. 1, 6, Vermes. G. E. Beer (Lipsiae, Germania).

Fichtel, L. von \& Moll. J. P. C. von 1798: Testacea microscopia aliaque minuta ex generibus Argonauta et Nautilus ad naturam delineata et descripta. XII +123 pp., 24 pls. Camesianische Buchhandlung, Wien.

Hansen, H. J. \& Reiss, Z. 1971: Electron microscopy of rotaliacean wall structures. Bull. geol. Soc. Denmark, 20, 329-346.

Le Calvez, Y. 1977: Revision des foraminifères de la collection d'Orbigny - Foraminifères de l'lle de Cuba. Tome 2. Cahiers de Micropaleont. 2, 131 pp. Paris.

Nyerup, R. \& Kraft, J. C. 1820: Almindeligt litteraturlexicon for Danmark, Norge og Island. 567-568 (In Danish).

Orbigny, A. D. d' 1826: Tableau méthodique de la classe des Céphalopodes. Ann. Sci. Nat. Paris, 1, 245-314.

Orbigny, A. D. d' 1839: Foraminifères in de la Sagra, R.: Histoire physique, politique et naturelle de l'lle de Cuba. 224 pp. Paris.

Snorrason, E.1974: C. G. Kratzenstein and his studies on electricity during the eighteenth century. Acta Hist. Sci. Nat. Med. 29, 206 pp. Odense University Press.

Spengler, L. 1781a: Nogle nyligen opdagede smaa snekkers beskrivelse. Kgl. dansk Vid. Selsk. Skr., Nye Saml. 1, 365-373, figs. 1-5. (In Danish).

Spengler, L. 1781b: Beskrivelse over nogle i havsandet nylig opdagede kokillier. Kgl. dansk Vid. Selsk. Skr., Nye Saml. 1, 374-383, figs. 7-10. (In Danish).

Steenstrup, J. 1849: Tvende breve fra Linné til conchyliesamleren Lorentz Spengler. Vid. Medd. naturhist. Foren. Kjøbenhavn, 1, 116-120. (In Danish).

Vedantam, D. \& Rao, M. S. 1970: Recent foraminifera from off Pentakota, east coast of India. Micropaleontology, 16, 325-344.

Wolff, T. 1968: The Danish expedition to "Arabia Felix" (1761-1767). Bull. Inst. Oceanogr. Monaco. Spec. Issue 2, $581-601,10$ figs. 